\title{
A guide to norms, ratings, and lists
}

\author{
JOHN L. BRADSHAW \\ Monash University, Clayton, Victoria, Australia
}

\begin{abstract}
A catalog of 119 studies, mostly post-1960 except for a few important and well-controlled earlier ones, is listed. The studies provide norms, scales, ratings, or lists of verbal material for use in experiments investigating aspects of cognitive psychology, memory, psycholinguistics, neuropsychology, etc. The catalog is preceded by an outline index.
\end{abstract}

The design of experiments in the areas of language, memory, cognition, and neuropsychology frequently demands the selection of verbal materials of known, scaled, normed, or rated properties in terms of, for example, confusability, frequency, familiarity, meaningfulness, associability, concreteness, etc., or the employment of items drawn from certain semantic or other categories. Many such lists, scales, norms, or ratings exist buried in the literature, and are not readily available to potential users. Indeed, 172 were catalogued by Brown (1976), up to 1974. However, his list was inevitably incomplete even at that date, and included many older studies of currently only limited interest. Since 1974, there have of course been many subsequent additions. I have concentrated mainly on post-1960 material, since this date seems to coincide with the general deployment of more sophisticated controls, although I have also included some important and standard works that predate 1960 . I have also concentrated mainly on comprehensive or relatively complete lists, rather than on small or idiosyncratic collections, although the latter have been included if they are otherwise interesting or unique.

Materials of the sort listed in the catalog may be derived from either objective or subjective approaches. The objective approach employs, for example, frequency counts of the occurrence of certain letters or words in written or spoken English. The subjective approach requires a sample group of subjects to estimate the frequency of occurrence of such items or, for example, to rate them for familiarity, meaningfulness, and so on. In cases in which objective measures are possible, they are obviously preferable. However, numerous studies have shown that in the context of everyday language, subjects' estimated frequencies generally do match quite closely the objective occurrence of a given variable. Often it is difficult or very time-consuming to obtain such objective information, and in many cases it is in principle obviously impossible, for example, in those cases in which

This research was supported by the Australian Research Grants Scheme. Requests for reprints should be addressed to J. L. Bradshaw, Department of Psychology, Monash University, Clayton, Victoria 3168, Australia. ratings for imageability, meaningfulness, etc., are sought. For this reason I have not specifically differentiated between the two complementary approaches, except when the heading makes it obvious, (e.g., "letter-frequency counts," etc.).

An outline index (Table 1) precedes the list of materials (Table 2) so that the potential user can access the source material of his or her choice. The index, inevitably idiosyncratic in its construction, moves from letters and digits to words, sentences, and pictures, and attempts to operate in a logical, hierarchical manner, grouping related ideas together. The numbers refer to the numbered, alphabetically arranged listing; this approach was adopted because many of the listed studies are relevant to a number of different issues or problems.

Table 1

Outline Index

\section{Letters and Digits}

Confusion Matrices

Visual (lowercase letters): 13, 28, 33

Visual (uppercase letters): $39,67,107$

Tactual (uppercase letters): $24,57,65$

Acoustic/auditory confusions: $23,47,67$

Nonword Letter Strings, CVCs, CVCVC Paralogs, CCC Strings Ease of association: $21,52,62,64,76,79,103$

Meaningfulness: $5,48,61,62,64,79,80,94,109$

Pronounceability: $42,60,61,62,80,81,94,109$

Orders of approximation to English: 44

Rated frequency: 64

Single letters (ratings for liking): 45

Letter-Frequency Counts and Versatility in Words Single Letters: 7, 70, 71, 96, 99, 100,109, 119

Digrams: $7,34,70,71,88,97,98,106,109,119$

Trigrams: $7,72,97,109$

Tetragrams: 73

Pentagrams: 74

Frequency Counts (Objective: See also Subjective Familiarity

Ratings Below)

Spoken: $10,46,55,112$

Written: $17,59,104,119$

Norms and Ratings for

Familiarity: $35,37,38,63,102,105$

Age of acquisition: $18,35,37,38,102$

Meaningfulness: $27,35,50,83,101,102,105$

Ease of recall: 20

Pronounceability: 101 
Table 1 (continued)

Categorizability: 105

Ease of definition: 11,58

Specificity: 101

Imagery: $11,27,30,35,37,38,49,83,102,105$

Enactive imagery: 63

Observability: 58

Picturability: 27

Animateness: 11

Concreteness: $16,27,30,35,37,38,41,58,83,101,105$, 116

Grammatical usage: 30

Pleasantness: 4, 16, 93, 105

Goodness: 16

Emotionality: 16

Semantic differential profile (evaluation, potency, activity): 43,51

Associative difficulty (see also Associations below): 16, 21 , 93

Associations

Words to digits: 9

Words to letters: 3

Words to words: $1,14,19,26,31,68,75,84,87,91$

Words to homographs: $25,32,40,56,85$

Words to spoken vowels: 29

Letters to letters and letter pairs: 2

Lists of Special Types of Word

Orthographically exceptional words: 22

Other orthographic variables (approximation to English, etc.): 30,90

Anagrams (single and multiple solution): $34,35,36,82,88,108$

Palindromes and heteropalindromes: 53, 54

Surnames (includes frequencies, familiarity, pronounceability, etc.): 118

Taxonomic categories and instances, prototypicality, etc.: 6 , $8,49,50,86,89,92,110$

Synonyms, and bidirectional synonym ratings: $113,114,115$

Homographs (primary and secondary meanings): $15,25,32$, $37,38,40,56,66,77,85,111,116,117$

Nonhomophonic homographs, heterophonic homographs, heterophones, heteronyms: 40,69

Polyphones: 69

\section{Sentences}

Incomplete sentences (norms for final word completion): 12

Tip-of-the-tongue general-knowledge questions (norms for correct answers): 78

Pictures

Norms for naming, familiarity, visual complexity, etc.: 95

Table 2

Catalog

1. Amste r, H. Convergent association norms for 10-year-old children and college age adults. Psychonomic Monograph Supplements, 1967, 2(1, Whole No. 17).

2. Amster, H., \& Keppei, G. Letter association norms. Psychonomic Monograph Supplements, 1966, 1(9, Whole No. 9).

3. Andergon, N. S. Word associations to individual letters. Journal of Verbal Learning and Verbal Behavior, 1965, 4, $541-545$.

4. Anisfield, M. Subjective approximation of relative letter incidence in pleasant and unpleasant English words. Journal of Verbal Learning and Verbal Behavior, 1968, 7, 33-40.
5. ArCher, E. J. A re-evaluation of the meaningfulness of all possible CVC trigrams. Psychological Monographs, 1960, 74(1, Whole No. 497).

6. Ashcraft, M. H. Property norms for typical and atypical items from 17 categories: A description and discussion. Memory \& Cognition, 1978, 6, 227-232.

7. Baddeley, A. D., Conrad, R., \& Thompson, W. E. Letter structure of the English language. Nature, 1960, 186, 414-416.

8. Battig, W. F., \& Montague, W. E. Category norms for verbal items in 56 categories: A replication and extension of the Connecticut norms. Journal of Experimental Psychology, 1969, 80, 1-46. (Monograph)

9. Battig, W. F., \& Spera, A. J. Rated association values of numbers from 0-100. Journal of Verbal Learning and Verbal Behavior, 1962, 1, 200-202.

10. Beier, E. G., Starkweather, J. A., \& Miller, D. E. Analysis of word frequencies in spoken language of children. Language and Speech, 1967, 10, 217-227.

11. Berrian, R. W., Metzler, D. P., Kroll, N. E. A., \& Clark-Meyers, G. M. Estimates of imagery, ease of definition, and animateness for 328 adjectives. Journal of Experimental Psychology: Human Learning and Memory, 1979, 5, 435-447.

12. Bloom, P. A., \& Fischler, I. Completion norms for 329 sentence contexts. Memory \& Cognition, 1980, 8, 631-642.

13. Bouma, $\mathrm{H}$. Visual recognition of isolated lower-case letters. Vision Research, 1971, 11, 459-474.

14. Bousfield, W. A., Cohen, B. H., Whitmarsh, G. A., \& Kincaid, W. D. The Connecticut free association norms (Tech. Rep. 35). Storrs, Conn: University of Connecticut, 1961.

15. Britron, B. K. Lexical ambiguity of words used in English text. Behavior Research Methods \& Instrumentation, 1978, 10, 1-7.

16. Brown, W. P., \& Ure, D. M. J. Five rated characteristics of 650 word association stimuli. British Journal of Psychology, 1969, 60, 233-249.

17. Carroll, J. B., Davies, P., \& Richman, B. Word frequency book. New York: American Heritage, 1971.

18. Carroll, J. B., \& White, M. N. Age-of-acquisition norms for 220 picturable nouns. Journal of Verbal Learning and Verbal Behavior, 1973, 12, 563-576.

19. Castaneda, A., Fahel, L. S., \& Odom, R. Associative characteristics of 63 adjectives and their relation to verbal paired-associate learning in children. Child Development, $1961,32,297-304$.

20. Christian, J., Bickley, W., Tarka, W., \& Clayton, $K$. Measures of free recall of 900 English nouns: Correlations with imagery, concreteness, and frequency. Memory \& Cognition, 1978, 6, 379-390.

21. Cievtat, V. J. Association indices for $\mathbf{4 4 6}$ randomly selected English monosyllables, bisyllables and trisyllables. Journal of Verbal Learning and Verbal Behavior, 1963, 2, 176-185.

22. Coltheart, M., Begner, D., Jonasson, J. T., \& Davelana, E. Phonological encoding in the lexical decision task. Quarterly Journal of Experimental Psychology, $1979,31,489-507$.

23. Conrad, R. Acoustic confusions in immediate memory. British Journal of Psychology, 1964, 55, 75-84.

24. Craig, J. C. A confusion matrix for tactually presented letters. Perception \& Psychophysics, 1979, 26, 409-411.

25. Cramer, P. A study of homographs. In L. Postman \& G. Keppel (Eds.), Norms of word association. New York: Academic Press, 1970.

26. Deese, J. The associative structure of some common English adjectives. Journal of Verbal Learning and Verbal Behavior, $1964,3,347-357$.

27. Еммекісн, H. J. Developmental differences in ratings of 
Table 2 (continued)

meaningfulness, concreteness and picturability. Develop mental Psychology, 1979, 15, 464-466.

28. Engel, G. R., Dougherty, W. G., \& Jones, G. B. Correlation and letter recognition. Canadian Journal of Psychology, 1973, 27, 317-326.

29. Forrester, W. E., \& TAmbs, C. A. Word associations to 19 vowels. Journal of Experimental Psychology: Human Learning and Memory, 1976, 2, 200-207.

30. Friendly, M., Franklin, P. E., Hoffman, D., \& Rubin, D. C. The Toronto word pool: Norms for imagery, concreteness, orthographic variables, and grammatical usage for 1,080 words. Behavior Research Methods \& Instrumentation, 1982, 14, 375-399.

31. Geen, R. G., \& Stonner, D. Primary associates to 20 verbs connoting violence. Behavior Research Methods \& Instrumentation, 1975, 7, 391-392.

32. Geis, M. F., \& Winograd, E. Norms of semantic encoding variability for fifty homographs. Bulletin of the Psychonomic Society, 1974, 3, 429-431.

33. Geyer, L. H. Recognition and confusion of the lowercase alphabet. Perception \& Psychophysics, 1977, 22, 487-490.

34. Gilhooly, K. J. Bigram statistics for 205 five-letter words having single-solution anagrams. Behavior Research Methods \& Instrumentation, 1978, 10, 389-392.

35. Gilhooly, K. J., \& HAY, D. Imagery, concreteness, ageof-acquisition, familiarity, and meaningfulness values for 205 five-letter words having single-solution anagrams. Behavior Research Methods \& Instrumentation, 1977, 9, 12-17.

36. Gilhooly, K. J., \& Johnson, C. E. Effects of solution word attributes on anagram difficulty: A regression analysis. Quarterly Journal of Experimental Psychology,1978, 30, 57-70.

37. Gilhooly, K. J., \& Logie, R. H. Age-of-acquisition, imagery, concreteness, familiarity, and ambiguity measures for 1,944 words. Behavior Research Methods \& Instrumentation, 1980, 12, 395-427.

38. Gilhooly, K. J., \& LoaıE, R. H. Meaning-dependent ratings of imagery, age-of-acquisition, familiarity, and concreteness for 387 ambiguous words. Behavior Research Methods \& Instrumentation, 1980, 12, 428-450.

39. Gilmore, G. C., Hersh, H., Caramazza, A., \& Griffin, J. Multidimensional letter similarity derived from recognition errors. Perception \& Psychophysics, 1979, 25, 425-431.

40. Gorfein, D. S., Viviani, J. M., \& Leddo, J. Norms as a tool for the study of homography. Memory \& Cognition, $1982,10,503-509$.

41. Gorman, A. M. Recognition memory for nouns as a function of abstractness and frequency. Journal of Experimental Psychology, 1961, 61, 23-29.

42. Hayden, B. S., \& Loud, L. Some norms for the pronunciability of nonsense syllables. Psychological Reports, 1969, 25, 415-418.

43. Heise, D. R. Semantic differential profiles for 1,000 most frequent English words. Psychological Monographs, 1965. 79(1, Whole No. 8)

44. Herata, K., \& Bryden, M. P. Tables of letter sequences varying in order of approximation to English. Psychonomic Science, 1971, 25, 322-324.

45. Horton, D. L., \& Mecherikoff, M. Letter preferences: Ranking the alphabet. Journal of Applied Psychology, $1960,4,252-253$

46. Howes, D. A word count of spoken English. Journal of Verbal Learning and Verbal Behavior, 1966, 5, 572-604.

47. Hull, A. J. A letter-digit matrix of auditory confusions. British Journal of Psychology, 1973, 64, 579-585.

48. Hunt, K. Meaningfulness ( $\mathrm{m}^{\prime}$ ) values for $300 \mathrm{CCCs}$. Behavior Research Methods \& Instrumentation, 1977, 9, 469. 470.
49. HuNT, $K$. Imagery values for taxonomic category names. Behavior Research Methods \& Instrumentation, 1978, 10, 750-752.

50. Hunt, K. P., \& Hodge, M. H. Category-item frequency and category-name meaningfulness $\left(\mathrm{m}^{\prime}\right)$ : Taxonomic norms for 84 categories. Psychonomic Monograph Supplements, $1971,4(6$, Whole No. 54).

51. Jenkins, J. J., Russell, W. A., \& Suci, G. J. An atlas of semantic profiles for 360 words. American Journal of Psychology, 1958, 71, 688-699.

52. Johnson, R. C. Mean associative latencies of $200 \mathrm{CVC}$ trigrams. Journal of Psychology, 1964, 58, 301-305.

53. Jone8, G. V. English palindromes: A distributional model. Behavior Research Methods \& Instrumentation, 1980, 12, 489-491.

54. Jones, G. V. Heteropalindromes. Behavior Research Methods \& Instrumentation, 1980, 12, 393-394.

55. Jones, L. V., \& WepMaN, J. M. A spoken word count. Chicago: Language Research Associates, 1966.

56. Kausler, D. H., \& Kollasch, S. F. Word associations to homographs. Journal of Verbal Learning and Verbal Behavior, $1970,9,444-449$.

57. Kikuchi, T., Yamashita, Y., Sagawa, K., \& Wake, T. An analysis of tactile letter confusions. Perception \& Psychophysics, 1979, 26, 295-301.

58. KLEE, H., \& Legae, D. Estimates of concreteness and other indices for 200 transitive verbs. Journal of Experimental Psychology: Human Learning and Memory, 1976, 2, 497-507.

59. Kučera, H., \& Francis, W. Computational analysis of present-day American English. Providence, R.I: Brown University Press, 1967.

60. Ley, R., \& KARKER, J. Pronunciability ratings of 319 CVCVC words and paralogs previously assessed for meaningfulness and associative reaction time. Bulletin of the Psy. chonomic Society, 1974, 3, 421-424.

61. LEY, R., \& Locascio, D. Associative reaction time and meaningfulness of CVCVC response terms in paired-associate learning. Journal of Experimental Psychology, 1970, 83, 445-450.

62. LEY, R., \& Tesiny, E. Associative reaction time, meaningfulness, and pronunciability ratings of 382 words and paralogs. Bulletin of the Psychonomic Society, 1975, 6, 645-648.

63. LiPPMAN, M. Z. Enactive imagery in paired associate learning. Memory \& Cognition, 1974, 2, 385-390.

64. Locascio, D., \& LEY, R. Scaled-rated meaningfulness of 319 CVCVC words and paralogs previously assessed for associative reaction time. Journal of Verbal Learning and Verbal Behavior, 1972, 11, 243-250.

65. Loomis, J. M. Tactile letter recognition under different modes of stimulus presentation. Perception \& Psychophysics, $1974,16,401-408$.

66. LoRae, I. The semantic count of the 570 commonest English words. New York: Bureau of Publications, Columbia University, 1949.

67. Manning, S. K. Ratings of the auditory and visual similarity of consonants: Implications for research. Behavior Research Methods \& Instrumentation, 1977, 9, 495-498.

68. Marshall, G. R., \& Cofer, C. N. Single-word freeassociation norms for 328 responses from the Connecticut cultural norms for verbal items in categories. In L. Postman \& G. Keppel (Eds.), Norms of word association. New York: Academic Press, 1970.

69. Martin, M., Jones, G. V., Nelson, D. L., \& Nelson, L. Heteronyms and polyphones: Categories of words with multiple phonemic representations. Behavior Research Methods \& Instrumentation, 1981, 13, 299-307.

70. Massaro, D. W., Taylor, G. A., Venezky, R. L., J Astrzembski, J. E., \& Lucas, P. A. Letter and word perception. Amsterdam: North-Holland, 1980. 
Table 2 (continued)

71. Mayzner, M. S., \& Tresselt, M. E. Tables of single-letter and digram frequency counts for various word-length and letter-position combinations. Psychonomic Monograph Supplements, 1965, 1(2, Whole No. 2).

72. Mayzner, M. S., Tresselt, M. E., \& Wolin, B. R. Tables of trigram frequency counts for various wordlength and letter-position combinations. Psychonomic Monograph Supplements, 1965, 1(3, Whole No. 3).

73. Mayzner, M. S., Tresselt, M. E., \& Wolin, B. R. Tables of tetragram frequency counts for various wordlength and letter-position combinations. Psychonomic Monograph Supplements, 1965, 1(4, Whole No. 4).

74. Mayzner, M. S., Tresselt, M. E., \& Wolin, B. R. Tables of pentagram frequency counts for various wordlength and letter-position combinations. Psychonomic Monograph Supplements, 1965, 1(5, Whole No. 5).

75. Mille R, K. M. Free-association responses of English and Australian students to 100 words from the Kent-Rosanoff word association test. In L. Postman \& G. Keppel (Eds.), Norms of word association. New York: Academic Press, 1970.

76. Montague, W. E., \& Kiess, H. U. The associability of CVC pairs. Journal of Experimental Psychology Monograph, $1968,78(2, \mathrm{Pt} .2)$.

77. Nelson, D. L., McEvoy, C. L., Walling, J. R., \& WheEle R, J. W. The University of South Florida homograph norms. Behavior Research Methods \& Instrumentation, 1980, 12, 16-37.

78. Nelson, T. O., \& Narens, L. Norms of 300 general-information questions: Accuracy of recall, latency of recall, and feeling-of-knowing ratings. Journal of Verbal Learning and Verbal Behavior, 1980, 19, 338-368.

79. Noвle, C. E. Measurements of association value (a), rated associations $\left(\mathrm{a}^{\prime}\right)$, and scaled meaningfulness $\left(\mathrm{m}^{\prime}\right)$ for the 2100 CVC combinations of the English alphabet. Psychological Reports, 1961, 8, 487.521.

80. Noble, C. E. Comparative pronounceability ratings (p) of 100 CVCs in two college populations. Psychonomic Science, 1967, 8, 433-434.

81. Nodine, C. F., \& HARDT, J. V. A measure of pronunciability of CVC trigrams. Behavior Research Methods \& Instrumenta. tion, 1969, 1, 210-216.

82. Olson, R., \& Schwarz, R. Single- and multiple-solution fiveletter words. Psychonomic Monograph Supplements, 1967, 2(8, Whole No. 24).

83. Paivio, A. V., Yuille, J. C., \& Madigan, S. A. Concreteness, imagery, and meaningfulness values for 925 nouns Journal of Experimental Psychology Monograph, 1968, 76 (1, Pt. 2).

84. Palermo, D. S., \& Jenkins, J. J. Word association norms: Grade school through college. Minneapolis: University of Minnesota Press, 1964.

85. Perfetti, C. A., Lindsey, R., \& Garson, B. Association and uncertainty: Norms of association to ambiguous words. Pittsburgh: University of Pittsburgh, Learning Research and Development Center, 1971.

86. Posnansxy, C. J. Category norms for verbal items in 25 categories for children in Grades 2-6. Behavior Research Methods \& Instrumentation, 1978, 10, 819-832.

87. Postman, L., \& KePPEL, G. (Eds.). Norms of word association. New York: Academic Press, 1970.

88. Rawlinson, G. E. Bigram frequency counts and anagram lists. Quarterly Journal of Experimental Psychology, 1976, 28, 125-142.

89. Rosch, E. Cognitive representation of semantic categories. Journal of Experimental Psychology: General, 1975, 104, 192-233.
90. RuBin, D. C. First-order approximation to English, secondorder approximation to English, and orthographic neighbor ratio norms for 925 nouns. Behavior Research Methods \& Instrumentation, 1981, 13, 713-721.

91. Shapiro, S. I., \& Palermo, D. S. An atlas of normative free association data. Psychonomic Monograph Supplements, 1968,2 (12, Whole No. 28).

92. Shapiro, S. I., \& Palermo, D. S. Conceptual organization and class membership: Normative data for representatives of 100 categories. Psychonomic Monograph Supplements, 1970, 3(11, Whole No. 43).

93. Silverstein, A., \& Dienstbier, R. A. Rated pleasantness and association value of 101 English nouns. Journal of Verbal Learning and Verbal Behavior, 1968, 7, 81-86.

94. Sмith, O. W., Badia, R., \& Rosenberg, B. G. Pronounceability ratings of some CVCs: Their reliability and relationship to m'. Psychological Reports, 1968, 23, 691-694.

95. Snodgrass, J. G., \& Vanderwatt, M. A standardized set of 260 pictures: Norms for name agreement, image agreement, familiarity and visual complexity. Journal of Experimental Psychology: Human Learning and Memory, 1980, 6, 174-215.

96. Solso, R. L. Positional frequency and versatility of letters for six-, seven-, and eight-letter English words. Behavior Research Methods \& Instrumentation, 1979, 11, 355-358.

97. Solso, R. L., \& Barbuto, P. F. Bigram and trigram frequencies and versatilities in the English language. Behavior Research Methods \& Instrumentation, 1979, 11, 475-484.

98. Solso, R. L., \& Juel, C. L. Positional frequency and versatility of bigrams for 2-through 9-letter English words. Behavior Research Methods \& Instrumentation, 1980, 12, 297.343.

99. Solso, R. L., Juel, C., \& Rubin, D. C. The frequency and versatility of initial and terminal letters in English words. Journal of Verbal Learning and Verbal Behavior, 1982, 21, 220-235.

100. Solso, R. L., \& KING, J. F. Frequency and versatility of letters in the English language. Behavior Research Methods \& Instrumentation, 1976, 8, 283-285.

101. Spreen, O., \& Schultz, R. W. Parameters of abstraction, meaningfulness, and pronunciability for 329 nouns. Journal of Verbal Learning and Verbal Behavior, 1966, 5, 459-468.

102. Stratton, R. P., Jacobus, K. A., \& Brinley, B. Age-ofacquisition, imagery, familiarity and meaningfulness norms for $\mathbf{5 4 3}$ words. Behavior Research Methods \& Instrumentation, 1975, 7, 1-6.

103. Taylor, J. D., \& Kimble, G. A. Association value of 320 selected words and paralogs. Journal of Verbal Learning and Verbal Behavior, 1967, 6, 744-752.

104. Thorndike, E. L., \& Lorae, I. The teacher's word book of 30,000 words. New York: Teacher's College Bureau of Publications, Columbia University, 1944.

105. Toglia, M. P., \& Battig, W. F. Handbook of semantic word norms. Hillsdale, N.J: Erlbaum, 1978.

106. Topper, G. E., Macey, W. H., \& Solso, R. L. Bigram versatility and bigram frequency. Behavior Research Methods \& Instrumentation, 1973, 5, 51-53.

107. Townsend, J. T. Theoretical analysis of an alphabetic confusion matrix. Perception \& Psychophysics, 1971, 9, 40-50.

108. Tresselt, M. E., \& Mayzner, M. S. Normative solution times for a sample of 134 solution words and 378 associated anagrams. Psychonomic Monograph Supplements, 1966, 1 (15, Whole No. 15).

109. Underwood, B. J., \& Schultz, R. W. Meaningfulness and verbal learning. Chicago: Lippincott, 1960.

110. UyedA, K. M., \& Mandler, G. Prototypicality norms for 28 semantic categories. Behavior Research Methods \& Instrumentation, 1980, 12, 587-595.

111. Warken, R. E., Bresnick, J. H., \& Green, J. P. Definitional dominance distributions for 20 English homographs. Bulletin of the Psychonomic Society, 1977, 10, 229-231. 


\section{Table 2 (continued)}

112. Wepman, J. M., \& Hass, W. A spoken word count. Chicago: Language Research Association, 1969.

113. Whitten, W. B., Suter, W. N., \& Frank, M. L. Bidirectional synonym ratings of $\mathbf{4 6 4}$ noun pairs. Journal of Verbal Learning and Verbal Behavior, 1979, 18, 109-127.

114. Wilding, J., \& Mohindra, N. Ratings of the degree of synonymity of 279 noun pairs. British Journal of Psychology, 1981, 72, 231-240.

115. Wildina, J., \& Mohindra, N. Preferred synonyms for each noun of 279 synonym pairs. British Journal of Psychology, 1983, 74, 91-100.

116. Wollen, K. A., Cox, S. D., Conhran, M. M., Shea, D. S., \& KIRBY, R. F. Frequency of occurrence and concreteness ratings of homograph meanings. Behavior Research Methods \& Instrumentation, 1980, 12, 8-15.
117. Yatzs, J. Priming dominant and unusual senses of ambiguous words. Memory \& Cognition, 1978, 6, 636-643.

118. Zechmeister, E. B., Kina, J., Gude, C., \& Opera-Nadi, B. Ratings of frequency, familiarity, orthographic distinctiveness, and pronunciability for 192 surnames. Behavior Research Methods \& Instrumentation, 1975, 7, 531-533.

119. Zetrensten, A. A word-frequency list based on American English press reportage. Copenhagen: University of Copenhagen, 1978.

\section{REFERENCE}

Brown, A. S. Catalog of scaled verbal material. Memory \& Cognition, 1976, 4, 1S-45S.

(Manuscript received June 24, 1983; revision accepted for publication July 29,1983 .)

\section{ANNOUNCEMENT \\ 25th Annual Meeting of The Psychonomic Society, Inc. - Change of Dates for Meeting}

The dates for the 25th annual meeting of The Psychonomic Society, Inc., have been changed:

From-November 1-3, 1984

To-November 8-10, 1984

The meeting still will be held at the Hilton Palacio Del Rio, San Antonio, Texas. 